\title{
High-level production of the agmatine in engineered Corynebacterium crenatum with the inhibition-releasing arginine decarboxylase
}

\author{
Fengyu Yang, Jiayu Xu, Yichun Zhu, Yi Wang, Meijuan Xu* and Zhiming Rao* (D)
}

\begin{abstract}
Background: Agmatine is a member of biogenic amines and is an important medicine which is widely used to regulate body balance and neuroprotective effects. At present, the industrial production of agmatine mainly depends on the chemical method, but it is often accompanied by problems including cumbersome processes, harsh reaction conditions, toxic substances production and heavy environmental pollution. Therefore, to tackle the above issues, arginine decarboxylase was overexpressed heterologously and rationally designed in Corynebacterium crenatum to produce agmatine from glucose by one-step fermentation.
\end{abstract}

Results: In this study, we report the development in the Generally Regarded as Safe (GRAS) L-arginine-overproducing C. crenatum for high-titer agmatine biosynthesis through overexpressing arginine decarboxylase based on metabolic engineering. Then, arginine decarboxylase was mutated to release feedback inhibition and improve catalytic activity. Subsequently, the specific enzyme activity and half-inhibitory concentration of 1534D mutant were increased 35.7\% and $48.1 \%$, respectively. The agmatine production of the whole-cell bioconversion with AGM3 was increased by $19.3 \%$ than the AGM2. Finally, $45.26 \mathrm{~g} / \mathrm{L}$ agmatine with the yield of $0.31 \mathrm{~g} / \mathrm{g}$ glucose was achieved by one-step fermentation of the engineered C. crenatum with overexpression of $s p e A_{1534 \mathrm{D}}$.

Conclusions: The engineered C. crenatum strain AGM3 in this work was proved as an efficient microbial cell factory for the industrial fermentative production of agmatine. Based on the insights from this work, further producing other valuable biochemicals derived from L-arginine by Corynebacterium crenatum is feasible.

Keywords: Corynebacterium crenatum, Agmatine, Arginine decarboxylase, Rational design, Feedback inhibition 


\section{Background}

Agmatine, also known as (4-aminobutyl) guanidine, one of the important biogenic amines, is widely applied in a variety of industrial fields such as pharmaceuticals [1], food, chemicals and feed [2]. As an important essence of medicine or nutrition, agmatine can enhance metabolism, regulate nutritional balance or accelerate body recovery and has gained interest from the medical industry $[3,4]$. In addition, agmatine has been shown to have neuroprotective effects in cases such as stroke, central nervous system traumas and neuropathic pain $[5,6]$. At present, the industrial production of agmatine mainly depends on the chemical method, which is often accompanied by problems such as low efficiency, harsh reaction conditions and heavy environmental pollution [7]. With the growing world market for agmatine, there is a significantly increased interest in the more efficient and economical production of agmatine. Therefore, it is necessary to find a safe and environmental-friendly biological approach for the production of agmatine.

The reaction from $\mathrm{L}$-arginine to agmatine is catalyzed with the enzyme arginine decarboxylase (ADC; EC 4.1.1.19) encoded by the speA or adiA gene [8, 9]. Currently, Escherichia coli is an attractive microbial chassis to produce various substances by metabolic engineering, since it has a clear genetic background [10-12]. Xu et al. had constructed a series of engineered $E$. coli for agmatine production [13, 14]. They first constructed an engineered $E$. coli for agmatine production through the deletion of speC and speF (encoding the ornithine decarboxylase isoenzymes), speB (encoding agmatinase) and $\arg R$ (encoding a transcriptional repressor). And then, the arginine decarboxylase gene speA from $E$. coli was overexpressed in the base strain AUX4, generating the strain AUX5. The engineered strain $E$. coli AUX5 produced $15.32 \mathrm{~g} / \mathrm{L}$ agmatine with a yield of $0.11 \mathrm{~g} / \mathrm{g}$ glucose in fed-batch fermentation [13]. Xu et al. used heterologous strong promoters sequentially to overexpress the genes encoding glutamate dehydrogenase $(g d h A)$, glutamine synthetase $(g \ln A)$, phosphoenolpyruvate carboxylase $(p p c)$, aspartate aminotransferase $(a s p C)$, transhydrogenase (pntAB), and L-arginine decarboxylase (speA) in the previously developed E. coli strain AUX4. They finally constructed an engineered $E$. coli strain AUX11 by metabolic engineering, which produced $40.43 \mathrm{~g} / \mathrm{L}$ of agmatine with a yield on the glucose of $0.29 \mathrm{~g} / \mathrm{g}$ [14]. In addition, the inducible arginine decarboxylase AdiA were overexpressed in E. coli at a $15-\mathrm{L}$ fermenter and $279.21 \mathrm{~g} / \mathrm{L}$ of agmatine was produced by whole-cell biotransformation with a conversion rate of $98 \%$ [15].

Corynebacterium crenatum is a Gram-positive bacterium and had been recognized as a well-established host to produce amino acids [16], chemicals [17], and natural products [18]. In contrast to E. coli, C. crenatum, a Generally Regarded as Safe (GRAS) strain, was the most commonly used industrial microorganism for the production of various amino acids and derivatives, including L-glutamate, L-arginine, and L-lysine [19]. Furthermore, C. crenatum possesses a strong metabolic flux to L-glutamate, making it a more potent producer of $\mathrm{L}$-arginine and its derivatives [20]. In our previous study, the base $C$. crenatum SYPA was developed and shown to be capable to overproduce L-arginine [21, 22]. Based on the above description, we are committed to broadening the product spectrum of Corynebacterium crenatum.

In this study, we report a metabolically engineered C. crenatum strain for enhancement the production of agmatine by overexpressing the arginine decarboxylase (ADC) on the recombinant plasmid (Fig. 1). To

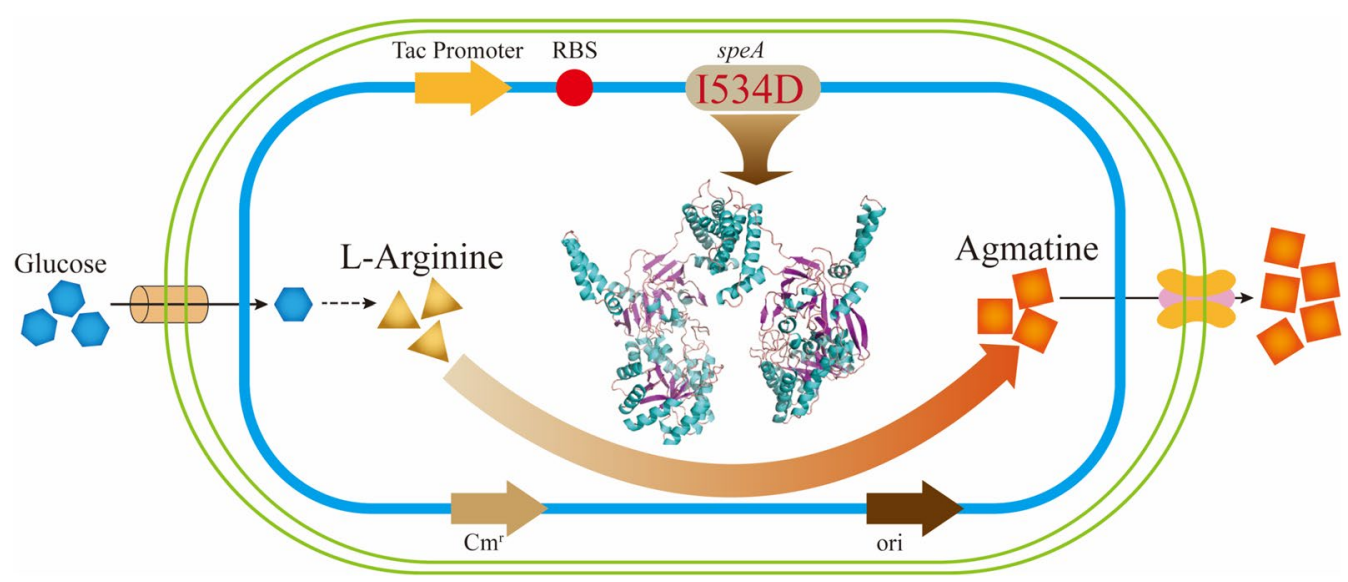

Fig. 1 Biosynthetic pathway from L-arginine to agmatine 
release agmatine inhibition of SpeA and improve the titer and yield of agmatine, we generated 16 mutants by site-directed mutagenesis. The best result showed that the half-inhibitory concentration and specific enzyme activity of the I534D mutant were $48.1 \%$ and $35.7 \%$ higher than those of the wild-type SpeA. Meanwhile, the agmatine production of whole-cell bioconversion with AGM3 was increased by $19.3 \%$ compared with AGM2. Finally, our engineered strain C. crenatum AGM3 was performed for synthesizing agmatine by fed-batch fermentation and allowed the production of $45.26 \mathrm{~g} / \mathrm{L}$ with the yield of $0.31 \mathrm{~g} / \mathrm{g}$ glucose. To the best of our knowledge, this is the first report for the production of agmatine by engineering Corynebacterium crenatum.

\section{Results}

\section{Construction of the engineered $C$. crenatum} by overexpressing arginine decarboxylase

Agmatine, an intermediate metabolite of the biogenic amines synthesis pathway, is produced from $\mathrm{L}$-arginine as the precursor [23]. In our previous work, L-arginine concentration in the fermentation supernatant was increased via the inactivation of arginine decarboxylase, which could direct the precursor molecules for the production of agmatine [24]. The arginine decarboxylase from E. coli was selected to produce agmatine [25], and C. crenatum SYPA was chosen as the chassis strain in this work due to its capability to overproduce L-arginine. Hence, genes encoding arginine decarboxylase from $E$. coli were overexpressed heterologously in the host strain. Two ADCs exist in $E$. coli, encoded by the constitutively expressed speA and the inducible adiA. AdiA is an inducible enzyme which is induced in a low $\mathrm{pH}$ growth environment [26], while SpeA is a constitutive enzyme and plays a role in the biosynthesis of agmatine [27]. The gene with a higher level of specific arginine decarboxylase activity among speA and adiA will be selected for the production of agmatine.

To effectively produce agmatine by $C$. crenatum SYPA, the shuttle plasmid pXMJ19 with an inducible strong tac promoter was selected as the vector. We cloned the ADC-coding gene into the pXMJ19 plasmid to construct a recombinant ADC expression plasmid. And then, the expression vectors were transformed into $C$. crenatum SYPA to generate two recombinant strains, termed AGM1 (C. crenatum SYPA/pXMJ19-adiA) and AGM2 (C. crenatum SYPA/pXMJ19-speA). The empty vector pXMJ19 was introduced into C. crenatum SYPA to generate the control strain AGM0.

\section{Activity assay and characterization of recombinant arginine decarboxylase}

After construction of the recombinant strains, the effect of overexpressing $\mathrm{ADC}$ on the agmatine production was analyzed using recombinant strains by whole-cell biotransformation. L-Arginine was added to the reaction mixture and was directly converted into agmatine by the recombinant strains with $\mathrm{ADC}$, which can clearly reflect the activity of arginine decarboxylase. Table 1 shows that the two arginine decarboxylases can direct the L-arginine for the production of agmatine and the AGM0 was used as a control strain. A total of $21.72 \mathrm{~g} / \mathrm{L}$ of agmatine in a $57.45 \%$ conversion ratio was produced from $\mathrm{L}$-arginine using AGM2, while a lower conversion ratio of $40.74 \%$ was obtained with AGM1. As we expected, without any agmatine was produced by the strain AGM0, and the crude enzyme activity analyses also demonstrated the above result (Table 2). Although the recombinant strain with heterologous expression of the speA gene from $E$. coli showed higher levels of agmatine production, in order to select the better enzyme for the next research, the enzymatic properties of the two ADCs were determined.

As shown in Table 2, arginine decarboxylase SpeA and AdiA were purified by His-Tag (His-Tag at C-terminal) and enzyme activity was determined. The specific activity of purified SpeA and AdiA were $55.7 \mathrm{U} / \mathrm{mg}$ and $46.4 \mathrm{U} /$ $\mathrm{mg}$, respectively. And the specific activity of purified SpeA was 6.2-fold higher than that of the crude cell extracts. Besides, $\mathrm{pH}$ and temperature are important parameters affecting enzyme activity and the result of whole-cell biotransformation and fermentation. Then, the properties of two arginine decarboxylases were further characterized by different temperatures and $\mathrm{pH}$ values. The optimum $\mathrm{pH}$ of ADC was measured from 5.0 to 10.0, and the maximum activity of SpeA was observed at pH 7.5 (Fig. 2a). In contrast, the maximum specific enzyme activity of AdiA appeared at $\mathrm{pH}$ 6.0. As described in Fig. 2b, the maximum activity of SpeA and AdiA was detected at $50,45^{\circ} \mathrm{C}$, respectively, when we measured the optimum temperature from 30 to $70{ }^{\circ} \mathrm{C}$. The catalytic activity of AdiA decreased significantly when the temperature exceeded $50{ }^{\circ} \mathrm{C}$. Based on these findings, SpeA was used for agmatine production in proceeding studies. The effect of metal ions on SpeA activity was shown in Fig. 2e, the enzyme activity was promoted $46.09 \%$ by $1 \mathrm{mM} \mathrm{Mg}^{2+}$. At the same time, the feedback inhibition of the product was next determined. We determined the enzyme activity by adding different concentrations of product to the reaction system. As shown in Fig. 2g, the results showed that the half-inhibitory concentration of SpeA was $5.4 \mathrm{~g} / \mathrm{L}$. In order to enhance the catalytic efficiency, SpeA was rationally designed to release feedback inhibition.

\section{Target residue selection for mutation and function determination}

The structure of arginine decarboxylase protein (PDB ID: $3 N Z Q$ ) from $E$. coli was used as the initial enzyme 
Table 1 The agmatine production of strains with different ADCs by whole-cell biotransformation

\begin{tabular}{lll}
\hline Strains & Agmatine (g/L) & Conversion rate (\%) \\
\hline C. crenatum AGM0 & ND & ND \\
C. crenatum AGM1 & $15.34 \pm 0.22$ & $40.74 \pm 0.58$ \\
C. crenatum AGM2 & $21.72 \pm 0.50$ & $57.45 \pm 0.84$ \\
\hline
\end{tabular}

ND means no data detected

Table 2 The arginine decarboxylase activities of crude extracts from engineering C. crenatum and purified enzyme from E. coli

\begin{tabular}{lll}
\hline Strains & Total activity $(\mathbf{U} / \mathbf{m L})$ & $\begin{array}{l}\text { Specific } \\
\text { activity (U/ } \\
\text { mg) }\end{array}$ \\
\hline C. crenatum AGM0 & ND & $\mathrm{ND}$ \\
C. crenatum AGM1 & $144.8 \pm 6.8$ & $8.3 \pm 0.5$ \\
C. crenatum AGM2 & $177.7 \pm 6.1$ & $8.9 \pm 0.3$ \\
Purified AdiA & $92.9 \pm 3.4$ & $46.4 \pm 1.9$ \\
Purified SpeA & $105.8 \pm 2.3$ & $55.7 \pm 1.2$ \\
\hline
\end{tabular}

ND means no data detected

structure. A tetramer was observed for arginine decarboxylase from E. coli, composed of two dimers of tightly associated monomers. The structure was visually displayed by Schrodinger, and the protein structure was pretreated (Fig. 3a). Then, the structure of arginine decarboxylase was docked with the molecule of agmatine that was pretreated. Mutations located in 531D, $533 \mathrm{~A}, 534 \mathrm{I}$ and 535D were close to the active center, may play a crucial role in releasing feedback inhibition. Virtual saturation mutagenesis library of four key amino acids was constructed by Schrodinger. The 16 mutants with improved prime stability were selected and listed in Additional file 1: Table S2. After the completion of site-directed mutagenesis, two mutants (I534D and I534S) with increased enzyme activity were identified by enzyme activity assay (Fig. 2f). The optimum temperature and $\mathrm{pH}$ of the two mutants were measured and found to be the same as that of the SpeA, except for an increase in enzyme activity. Catalytic activity decreased significantly when the temperature exceeded $60{ }^{\circ} \mathrm{C}$ (Fig. 2d). Meanwhile, two mutants and SpeA had more than $90 \%$ residual activity after incubation for $12 \mathrm{~h}$ under neutral conditions (Fig. 2c). As shown in Fig. 2g, the half-inhibitory concentration of I534D was increased from $5.4 \mathrm{~g} / \mathrm{L}$ to $8.0 \mathrm{~g} / \mathrm{L}$ compared with wild-type SpeA.

According to previous reports, residues which were adjacent to the active center played an important role in catalytic efficiency [28]. In our studies, the I534 site was near the active center, thus I534 acted a crucial role in catalytic activity. Thus, mutating the hydrophobic isoleucine $(+4.5)$ into hydrophilic aspartic acid $(-3.5)$ decreased the affinity for the product agmatine, reducing feedback inhibition. Meanwhile, the mutation of serine $(-0.8)$, which was relatively less hydrophilic, also had a little effect on releasing feedback inhibition. In addition, the catalytic efficiency of mutant I534D was increased compared with wildtype SpeA, which may be attributed to the smaller side chain and the release of feedback inhibition after mutation [29] (Fig. 3c). Furthermore, the Kcat/Km of I534D was 1.42 times higher than SpeA, indicating that I534D significantly improved catalytic efficiency (Table 3). Although the substrate affinity of the I534D mutant was reduced, the Kcat was increased 1.48-fold seems to result from the enhanced product release. And our results can be supported by previous study [30].

The gene encoding mutant I534D was linked with the shuttle plasmid pXMJ19 to construct recombinant expression plasmid and it was transformed into strain C. crenatum SYPA to produce AGM3 (C. crenatum SYPA/pXMJ19-speA $\left.A_{\text {I534D }}\right)$.

\section{Recombinant whole-cell bioconversion for the production of agmatine}

A mutant that can reduce the inhibition of the product was selected through rational modification, and its catalytic activity was also increased compared with SpeA. The production of agmatine by whole-cell biotransformation was used to test the effect of L-arginine decarboxylase mutation [31]. The effect of the final $\mathrm{OD}_{600}$ value, substrate concentration, temperature, $\mathrm{pH}, \mathrm{PLP}$ and $\mathrm{Mg}^{2+}$ on agmatine production was determined. The amount of cell in the transformation mixture is one of the crucial factors

\footnotetext{
(See figure on next page.)

Fig. 2 Biochemical characterization of ADCs and mutations. a Effect of pH on ADCs and mutations activity. $\mathbf{b}$ Effect of temperature on ADCs and mutations activity. c Residual activity of SpeA and its mutations after incubated for $12 \mathrm{~h}$ at different $\mathrm{pH}$ buffers. The initial activity before incubation was defined as $100 \%$. d Residual activity of SpeA and its mutations after incubated for $12 \mathrm{~h}$ at different temperatures. The initial activity before incubation was defined as $100 \%$. e Effect of metal ions on wild-type SpeA activity. $\mathbf{f}$ Specific enzyme activities of different SpeA variants. The wild-type SpeA enzyme activity was defined to $100 \%$. $\mathbf{g}$ The enzyme activity of wild-type SpeA and mutations at different agmatine concentrations. $\mathbf{h}$ The enzyme activity of wild-type SpeA and mutations at high agmatine concentrations. The enzyme activity without agmatine was defined as $100 \%$. All determinations were performed in triplicate
} 

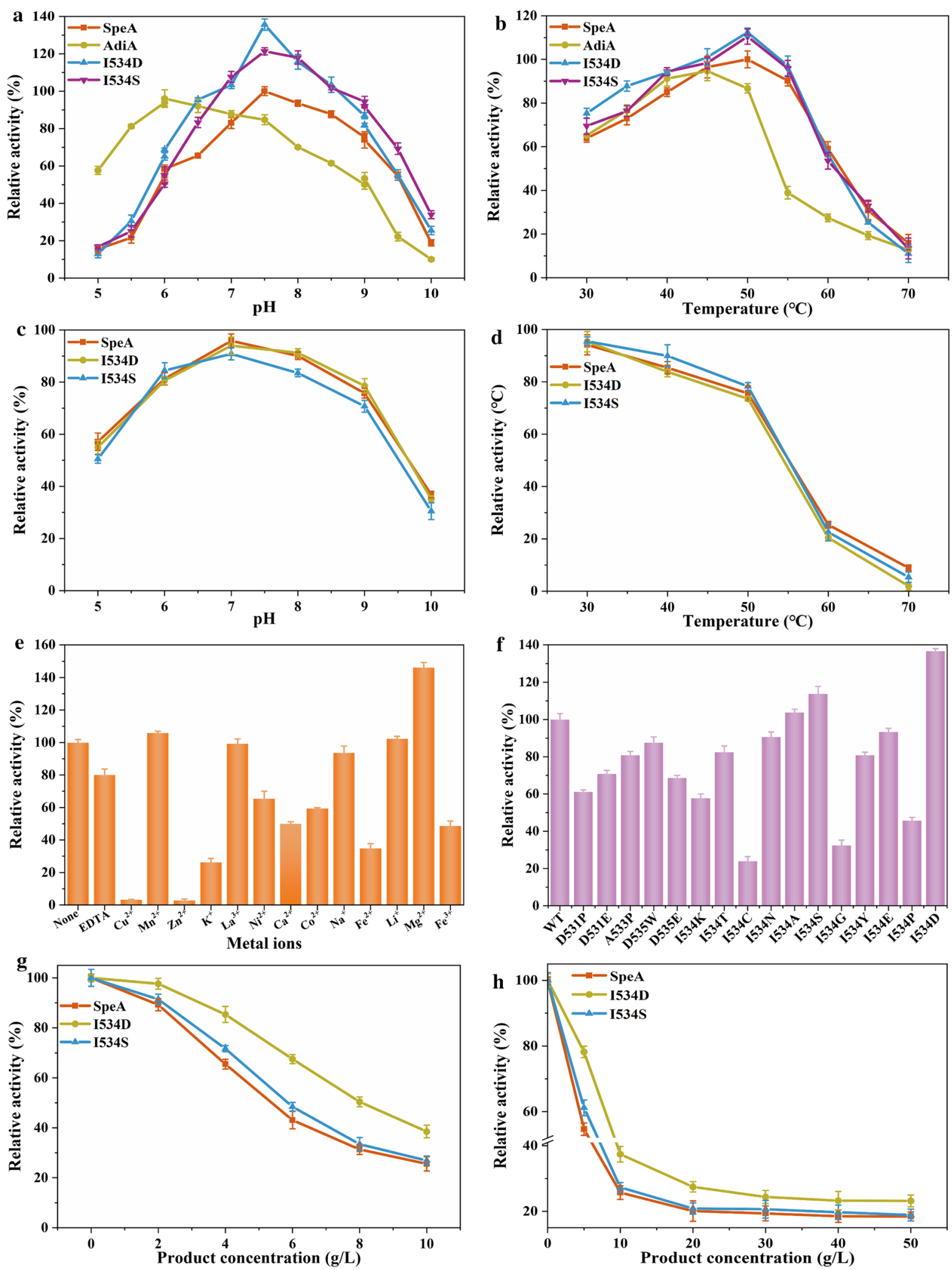

Fig. 2 (See legend on previous page.) 

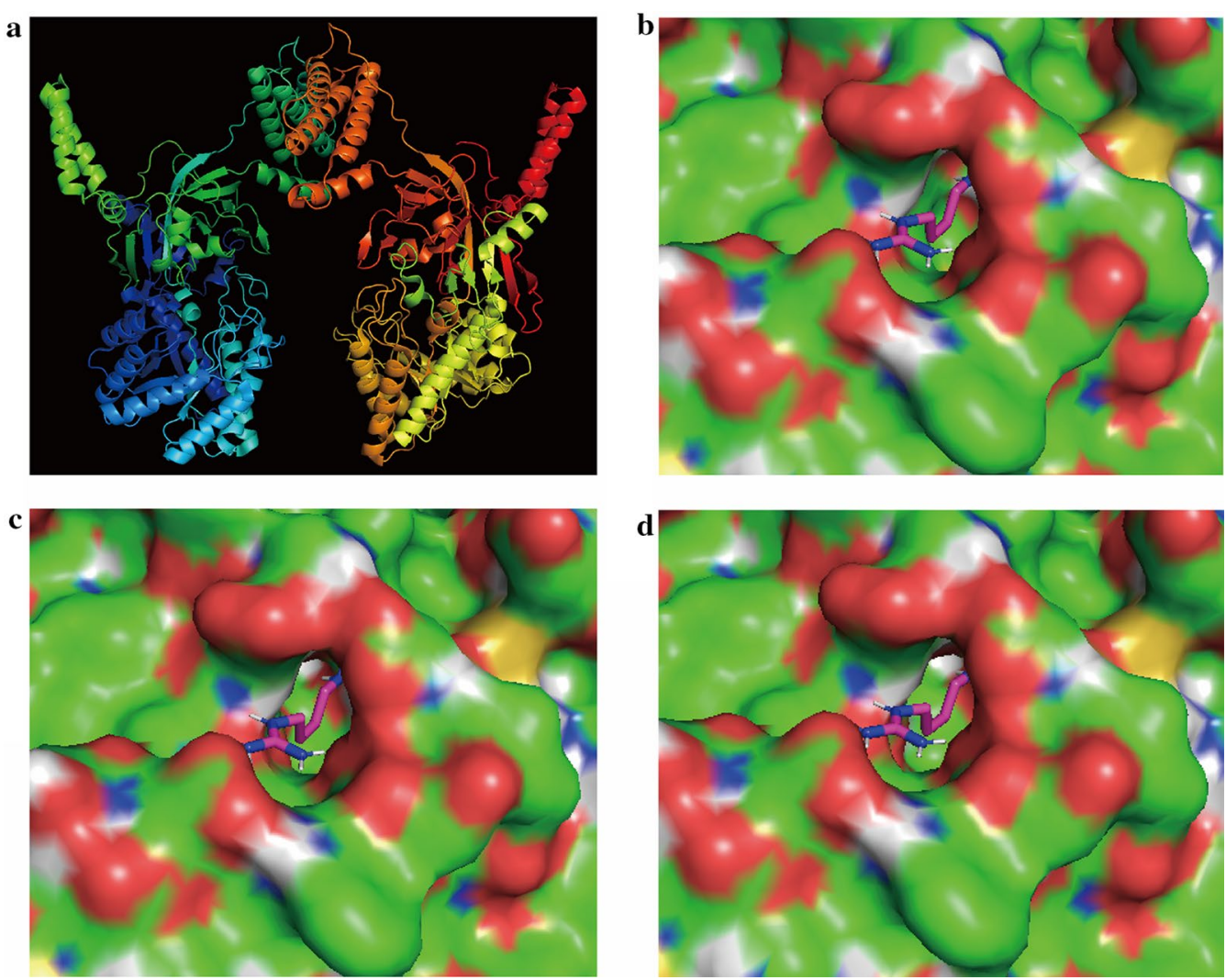

Fig. 3 The structure of wild-type SpeA and the structural analysis of SpeA, 1534D and I534S after docking agmatine. a The structure of wild-type SpeA. $\mathbf{b}$ Changes in product docking site on the surface of SpeA. $\mathbf{c}$ Changes in product docking site on the surface of I534D. $\mathbf{d}$ Changes in product docking site on the surface of 1534 S

in the transformation reaction. As shown in Fig. 4a, when the final $\mathrm{OD}_{600}$ value of $C$. crenatum cells reached 40 , the optimal agmatine titer was $25.68 \mathrm{~g} / \mathrm{L}$ with a conversion rate of $68.19 \%$. As shown in Fig. $4 \mathrm{~b}$, the optimal substrate concentration of AGM3 appears at $50 \mathrm{~g} / \mathrm{L}$, the conversion production decreased when other concentrations were added. When $40 \mathrm{~g} / \mathrm{L} \mathrm{L}$-arginine was added, the agmatine yield of AGM2 was highest. By adjusting the temperature from 30 to $60{ }^{\circ} \mathrm{C}$, the maximum agmatine titer was observed at $50{ }^{\circ} \mathrm{C}$ for both AGM2 and AGM3 (Fig. 4c). The agmatine titer was increased gradually from 30 to $50{ }^{\circ} \mathrm{C}$ but decreased significantly from 50 to $60{ }^{\circ} \mathrm{C}$. The highest agmatine titer was achieved at $50{ }^{\circ} \mathrm{C}$, and the agmatine titer was $29.81 \mathrm{~g} / \mathrm{L}$ at a conversion rate of $79.18 \%$. We assayed the agmatine concentration using whole-cell bioconversion by changing the $\mathrm{pH}$ from 6.0 to 9.0. At $\mathrm{pH} 8.0$, the highest production of $31.37 \mathrm{~g} / \mathrm{L}$ was formed and the titer of agmatine dropped with the $\mathrm{pH}$ decrease (Fig. 4d). At $\mathrm{pH}$ 9.0, the catalyst activity decreased and a lower titer of agmatine was formed. PLP is essential for arginine decarboxylase and the catalytic activity of arginine decarboxylase can be improved when
Table 3 The kinetic parameters of wild-type SpeA and mutants towards substrates L-arginine

\begin{tabular}{llll}
\hline & WT & I534D & I534S \\
\hline $\mathrm{Km}(\mathrm{mM})$ & $0.602 \pm 0.092$ & $0.623 \pm 0.075$ & $0.691 \pm 0.069$ \\
$\mathrm{Kcat}\left(\mathrm{S}^{-1}\right)$ & $1.788 \pm 0.135$ & $2.643 \pm 0.328$ & $2.121 \pm 0.206$ \\
$\mathrm{Kcat} / \mathrm{Km}\left(\mathrm{S}^{-1} \mathrm{mM}^{-1}\right)$ & 2.97 & 4.242 & 3.069 \\
$\mathrm{IC}_{50}(\mathrm{~g} / \mathrm{L})$ & $5.4 \pm 0.19$ & $8.0 \pm 0.21$ & $5.9 \pm 0.24$ \\
$\mathrm{Ki}(\mathrm{mM})$ & $4.42 \pm 0.32$ & $6.59 \pm 0.45$ & $5.46 \pm 0.39$ \\
\hline
\end{tabular}

PLP was added [32]. As shown in Fig. 4e, the catalysis efficiency was highest when $5 \mathrm{mM}$ PLP was added to the transformation broth and $31.66 \mathrm{~g} / \mathrm{L}$ agmatine could be produced in $12 \mathrm{~h}$. The agmatine titer of the mutant increased from 30.11 to $32.55 \mathrm{~g} / \mathrm{L}$ in $12 \mathrm{~h}$ from $50 \mathrm{~g} / \mathrm{L}$ $\mathrm{L}$-arginine at different $\mathrm{Mg}^{2+}$ concentrations (Fig. 4f). As the concentration of $\mathrm{Mg}^{2+}$ increased, the highest agmatine titer was achieved at $3 \mathrm{mM}$, and then agmatine decreased with increasing $\mathrm{Mg}^{2+}$ concentrations. 

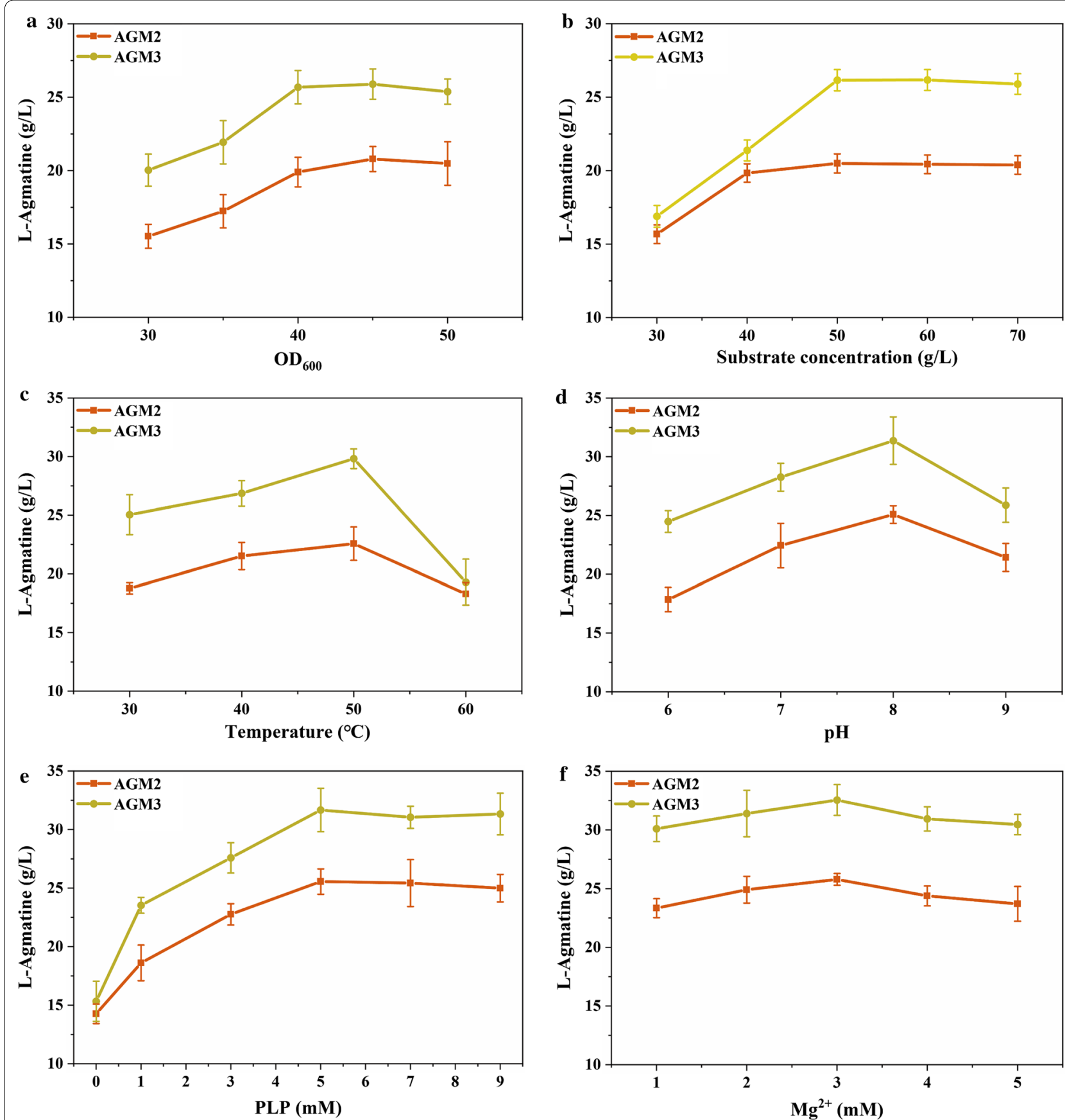

Fig. 4 Optimization of whole-cell biotransformation conditions for agmatine production. $\mathbf{a}$ The cell density of the biotransformation system. $\mathbf{b}$ The substrate concentration of the biotransformation system. $\mathbf{c}$ The temperature of the biotransformation system. $\mathbf{d}$ The pH of the biotransformation system. $\mathbf{e}$ The PLP concentration of the biotransformation system. $\mathbf{f}$ The $\mathrm{Mg}^{2+}$ concentration of the biotransformation system. All determinations were performed in triplicate

On the basis of the optimized transformation conditions described above, the reaction system was added $50 \mathrm{~g} / \mathrm{L} \mathrm{L}$-arginine at 0 and $6 \mathrm{~h}$. In short, the reaction mixture included $100 \mathrm{~g} / \mathrm{L} \mathrm{L}$-arginine, $5 \mathrm{mM}$ PLP, $3 \mathrm{mM} \mathrm{Mg}^{2+}$, the $\mathrm{OD}_{600}=40$ of induced cells and $50 \mathrm{mM}$ Tris- $\mathrm{HCl}$ buffer ( $\mathrm{pH}$ 8.0). Finally, the agmatine production of whole-cell bioconversion with AGM3 was $62.84 \mathrm{~g} / \mathrm{L}$ at a conversion rate of $83.44 \%$ in $12 \mathrm{~h}$, but only a lower level of $48.24 \mathrm{~g} / \mathrm{L}$ agmatine was produced in recombinant strain AGM2 (Table 4). 


\section{One-step preparation of agmatine from glucose was realized by $C$. crenatum}

We engineered $C$. crenatum strain for the production of agmatine using L-arginine as the substrate that may compete with the use of L-arginine in pharmaceuticals and feed industries. Glucose, an inexpensive and attractive sustainable fermentation raw material, is an excellent raw material for the production of various high value-added compounds and was used for the production of agmatine to address this problem. AGM0 was used as the control strain, shaking flask cultures of AGM2 and AGM3 with glucose as substrate supply was carried out to compare the $\mathrm{OD}_{600}$ and agmatine titer of engineered strain C. crenatum. As shown in Fig. 5a, C. crenatum AGM0 grew with a rate of $0.23 \mathrm{~h}^{-1}$ to a final biomass concentration of $21.93 \mathrm{~g} / \mathrm{L}$. The overexpression of arginine decarboxylase affected the cell growth, resulting in the cell dry weight of AGM2 and AGM3 lower than that of the control strain. C. crenatum AGM3 grew with a rate of $0.18 \mathrm{~h}^{-1}$ to a final cell dry weight concentration of $17.71 \mathrm{~g} / \mathrm{L}$ and the cell density measurement showed no significant differences between AGM2 and AGM3. These results indicate that AGM0 is unable to produce agmatine, although the cell density of AGM0 was higher than the other two strains (Fig. 5b). As described in Fig. 5b, a total of $15.53 \mathrm{~g} / \mathrm{L}$ of agmatine was produced from glucose using C. crenatum AGM2, while a high level of agmatine was obtained with AGM3. Agmatine was produced to a titer of $17.96 \mathrm{~g} / \mathrm{L}$ corresponding to a yield of $0.16 \mathrm{~g} / \mathrm{g}$ glucose by $C$. crenatum AGM3. After fermentation, the strain AGM2 produced $1.68 \mathrm{~g} / \mathrm{L}$ L-arginine, which was not found in AGM3, which may be due to the relatively low catalytic activity and the feedback inhibition of wild-type SpeA. These results illustrated that the yield of agmatine could be increased by releasing feedback inhibition of SpeA. In addition, the neutrality of fermentation broth by the production of agmatine relative to L-arginine may also be a reason for the high agmatine yield. The expression of SpeA mutant in the AGM3 strain was optimized by adding different concentrations of the inducer isopropyl $\beta$-D-1-thiogalactopyranoside (IPTG) at $24 \mathrm{~h}$. And then, resulting in the production of $18.9 \mathrm{~g} / \mathrm{L}$ of agmatine after fermentation of $96 \mathrm{~h}$ when $0.7 \mathrm{mM}$ was added (Fig. 5c).

\section{Enhanced production of agmatine using fed-batch strategy}

Finally, to further test the performance of engineered strain C. crenatum AGM3 for large-scale production of agmatine, fed-batch fermentations were carried out in a 5-L bioreactor with industrially relevant complex medium using glucose as carbon sources. The time profiles of fed-batch fermentation of the C. crenatum AGM3 were shown in Fig. 6. In the first stage (0-24 h), biomass
Table 4 The whole-cell biotransformation on agmatine production under optimized conditions in C. crenatum AGM2 and AGM3

\begin{tabular}{lll}
\hline Strains & Agmatine (g/L) & Conversion rate (\%) \\
\hline C. crenatum AGM2 & $48.24 \pm 1.61$ & $64.05 \pm 2.14$ \\
C. crenatum AGM3 & $62.84 \pm 0.64$ & $83.43 \pm 0.85$ \\
\hline
\end{tabular}

was accumulated rapidly and achieved the DCW of $13.3 \mathrm{~g} / \mathrm{L}$, while glucose consumption was slow. The production of agmatine in the first stage may be due to the leaky expression of inducible promoter tac. With the induction of $0.7 \mathrm{mM}$ IPTG at $24 \mathrm{~h}$, a high accumulation of agmatine was observed with a high production rate up to $0.79 \mathrm{~g} / \mathrm{L} / \mathrm{h}$ during the phase of fermentation (24$72 \mathrm{~h}$ ). Contrarily, the growth of the strain AGM3 became slower than the time before $24 \mathrm{~h}$ due to the addition of IPTG. At the end of fermentation, the C. crenatum AGM3 strain was able to produce $45.26 \mathrm{~g} / \mathrm{L}$ of agmatine with the yield of $0.31 \mathrm{~g} / \mathrm{g}$ glucose and achieved the productivity of $0.47 \mathrm{~g} / \mathrm{L} / \mathrm{h}$. Different from shaking flask cultivations of the engineered strains AGM3, a small amount of extracellular intermediate metabolites L-arginine was produced in the culture medium before $24 \mathrm{~h}$ and maintained at a low-level titer of around $1.6 \mathrm{~g} / \mathrm{L}$ during fedbatch fermentation. The maximum biomass was reached after $96 \mathrm{~h}$ fermentation and achieved the highest DCW of $28.44 \mathrm{~g} / \mathrm{L}$. Those are the highest value for agmatine production from $C$. crenatum, demonstrating that the engineered strain C. crenatum AGM3 is a competitive platform strain for agmatine production.

\section{Conclusions}

In this study, $C$. crenatum was engineered for the first time to produce agmatine. The agmatine synthesis pathway was reconstructed and key catalytic steps were enhanced by screening efficient enzyme variants with high catalytic activity and agmatine tolerance. Compared with wild-type SpeA, the half-inhibitory concentration and specific enzyme activity of I534D were increased by $48.1 \%$ and $35.7 \%$, respectively. The agmatine production of whole-cell bioconversion with AGM3 was $62.84 \mathrm{~g} / \mathrm{L}$ in $12 \mathrm{~h}$ with a conversion rate of $83.44 \%$ and the yield was increased by $19.3 \%$ compared with AGM2. The final AGM3 strain can produce $45.26 \mathrm{~g} / \mathrm{L}$ of agmatine with a yield of $0.31 \mathrm{~g} / \mathrm{g}$ glucose in fed-batch fermentation. This result represented the highest yield of agmatine synthesized by $C$. crenatum. The present study also represents the first report on the efficient production of agmatine from low-value raw materials using $C$. crenatum, 

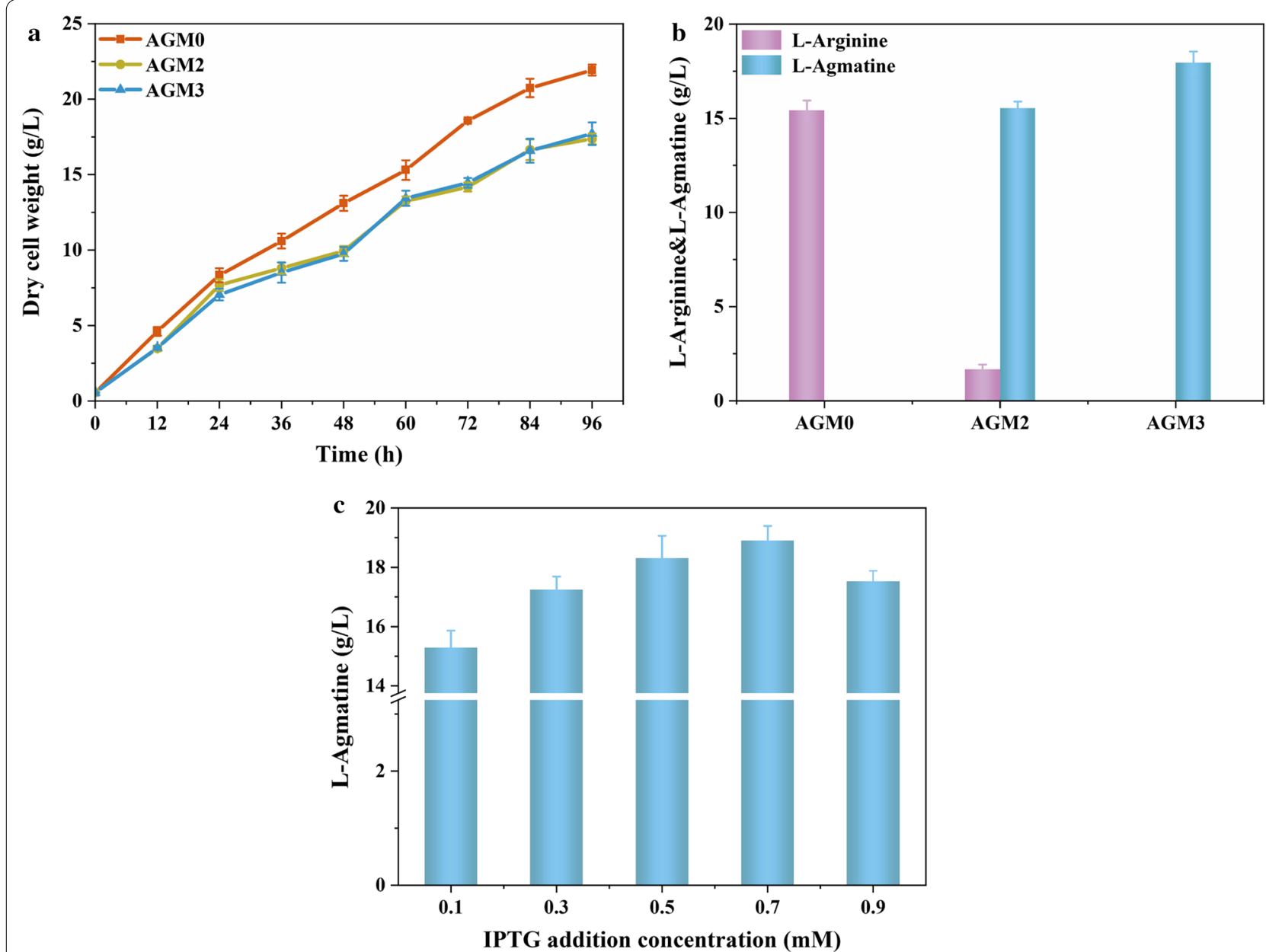

Fig. 5 Effect of modifying arginine decarboxylase on agmatine production in shaking flask. a The dry cell weight of AGMO, AGM2 and AGM3. b Agmatine production of strains AGM0, AGM2 and AGM3. c Agmatine production of strain AGM3 by adding different concentrations of IPTG. All determinations were performed in triplicate

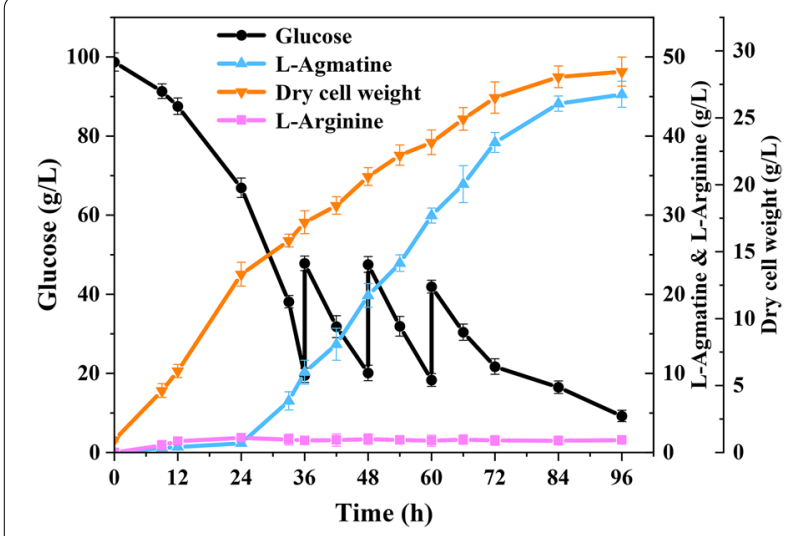

Fig. 6 Time profile of agmatine production by recombinant $C$. crenatum AGM3 in fed-batch fermentation. All determinations were performed in triplicate providing an avenue for the efficient industrial fermentative production of agmatine.

\section{Materials and methods}

\section{Bacterial strains, plasmids and materials}

The bacterial strains and plasmids used in this study are listed in Additional file 1: Table S1. The arginine decarboxylase was encoded by the genes of speA (Gene ID: 947432) and adiA (Gene ID: 948638) from Escherichia coli $\mathrm{K}-12$. The strain used for heterologous expression was E. coli BL21 (DE3) and C. crenatum SYPA was used as an agmatine producer. The shuttle vector pXMJ19 was used for gene expression and mutagenesis studies in $E$. coli BL21 (DE3) and C. crenatum SYPA. DNA polymerases $(2 \times$ Phanta Max Master Mix, $2 \times$ Taq Max Master 
Mix) used for PCR were purchased from Vazyme Biotech Co. Ltd. (Nanjing, China). Agmatine was purchased from Aladdin (Shanghai, China). All other chemicals of high grade were obtained from commercial sources.

\section{Structural analysis and molecular docking}

The three-dimensional structure model of SpeA was downloaded from the Protein Data Bank (PDB) and PDB ID: 3NZQ [33]. The agmatine and L-arginine were docked into the protein structure by Schrodinger. The prime stability score of each docking intermediate complex was calculated, and the best docking position was selected by docking analysis. The best mutations score of prime stability were listed in Additional file 1: Table S2. Mutants of SpeA were modeled by introducing the mutated residues into the wild-type model.

\section{Cloning and site-directed mutagenesis of arginine decarboxylase}

The speA gene coding for arginine decarboxylase was amplified by PCR using the E. coli genomic DNA as a template. The linear fragments of the amplified products were inserted into the $B a m H$ I and EcoR I sites of the pXMJ19 vector. Mutations were introduced by overlapping PCR using the primers listed in Additional file 1: Table S3. The recombinant plasmids were finally transformed into E. coli BL21 (DE3) for expression and the success of the desired mutation was confirmed by DNA sequencing. The recombinant plasmids were transformed into C. crenatum SPYA using the electroporation method described by Tauch et al. [34].

\section{Expression and purification of proteins}

All recombinant proteins expressed in E. coli or C. crenatum SPYA were labeled with a His-Tag at C-terminally. In order to express arginine decarboxylase, recombinant E. coli were cultured at $37^{\circ} \mathrm{C}$ in $\mathrm{LB}$ medium until $\mathrm{OD}_{600}$ reached about 0.6. Then, isopropyl $\beta$-D-1thiogalactopyranoside (IPTG) was added at a final concentration of $0.5 \mathrm{mM}$, and the strains were cultured at $16{ }^{\circ} \mathrm{C}$ for $12 \mathrm{~h}$ to induce the expression of the protein. The $C$. crenatum cells were cultured and induced in LBG medium for $18 \mathrm{~h}$ at $30^{\circ} \mathrm{C}$. After cultivation, the cells were collected by centrifugation at $8000 \times g$ and $4{ }^{\circ} \mathrm{C}$ for $5 \mathrm{~min}$, washed twice and suspended in Tris- $\mathrm{HCl}$ buffer ( $\mathrm{pH}$ 8.0). The cell suspension was disrupted on ice by sonication and the cell crude extract was obtained by centrifugation at $10,000 \times g$ and $4{ }^{\circ} \mathrm{C}$ for $20 \mathrm{~min}$. After that, the proteins were purified using the HisTrap ${ }^{\mathrm{TM}} \mathrm{HP}$ affinity column $(5 \mathrm{~mL})$ and the AKTA protein purifier (GE Healthcare, Sweden). The target proteins were eluted by buffer $\mathrm{M}_{0}$ (20 mM Tris- $\mathrm{HCl}, 500 \mathrm{mM} \mathrm{NaCl}, \mathrm{pH}$ 7.4) and $\mathrm{M}_{700}(20$
$\mathrm{mM}$ Tris- $\mathrm{HCl}, 700 \mathrm{mM}$ imidazole, $500 \mathrm{mM} \mathrm{NaCl}, \mathrm{pH}$ 7.4) with a gradient ratio. The purified enzymes were analyzed by SDS-PAGE.

\section{Determining specific enzyme activity, biochemical properties and feedback inhibition of ADC}

The enzyme activity of ADC was determined according to the amount of agmatine produced at $37^{\circ} \mathrm{C}$ for $10 \mathrm{~min}$ [35]. The reaction mixture contained $50 \mathrm{mM}$ Tris- $\mathrm{HCl}$ buffer (pH 8.0), $50 \mathrm{mM}$ L-arginine, $2.5 \mathrm{mM} \mathrm{MgSO}_{4}, 0.6$ $\mathrm{mM}$ pyridoxal phosphate (PLP) and an appropriate amount of purified enzyme. The reaction was stopped by the addition of $500 \mu \mathrm{L} 40 \%$ trichloroacetic acid. One unit of ADC activity is defined as the amount of enzyme that generated $1 \mu \mathrm{mol}$ agmatine per minute. The L-arginine and agmatine concentrations were measured by HPLC. With bovine serum albumin (BSA) as the standard, the purified protein concentration was determined by Bradford [36].

The optimal temperature of $\mathrm{ADC}$ was determined by changing the temperature range from $30^{\circ} \mathrm{C}$ to $70{ }^{\circ} \mathrm{C}$. The optimum $\mathrm{pH}$ of $\mathrm{ADC}$ was measured by changing different $\mathrm{pH}$ values from 5.0 to 10.0 . Thermostability was measured by incubating purified enzyme in the temperature range of $30^{\circ} \mathrm{C}$ to $70{ }^{\circ} \mathrm{C}$ for $12 \mathrm{~h}$ at $\mathrm{pH} 8.0$, then the residual enzyme activity was determined. In addition, the $\mathrm{pH}$ stability was determined by culturing purified enzyme in different $\mathrm{pH}$ buffers from 5.0 to 10.0 for $12 \mathrm{~h}$. The activity of the enzyme without incubation was defined as $100 \%$. The influence of metal ions on enzyme activity was measured using $1 \mathrm{mM} \mathrm{Mg}{ }^{2+}, \mathrm{Zn}^{2+}, \mathrm{Mn}^{2+}$, $\mathrm{Ca}^{2+}, \mathrm{Fe}^{2+}, \mathrm{Cu}^{2+}, \mathrm{Na}^{+}, \mathrm{Ni}^{2+}, \mathrm{Co}^{2+}, \mathrm{Li}^{+}, \mathrm{Fe}^{3+}, \mathrm{La}^{3+}$, and $\mathrm{K}^{+}$separately. The method of measuring enzyme activity was consistent with that described above. The activity of the enzyme without metal ions was defined as $100 \%$.

The method of feedback inhibition determination was similar to that of SpeA activity determination, the only difference was that we added different concentrations of agmatine to the enzymatic reaction mixture. The inhibition curve was constructed by changing the concentration of agmatine in the reaction mixture. The activity of SpeA without agmatine was defined as $100 \%$.

\section{Whole-cell bioconversion and production of agmatine}

A 50-mL whole-cell conversion was performed in a 250 $\mathrm{mL}$ airtight container. For the production of agmatine by whole-cell bioconversion, $50 \mathrm{~g} / \mathrm{L} \mathrm{L}$-arginine was dissolved in $50 \mathrm{mM}$ Tris- $\mathrm{HCl}$ buffer, including $\mathrm{MgSO}_{4}$, pyridoxal phosphate (PLP), and an appropriate amount of recombinant $C$. crenatum cells. Whole $C$. crenatum cells were added to this reaction solution with different final $\mathrm{OD}_{600}$ values $(30,35,40,45$ and 50$)$. The $\mathrm{pH}$ value of the reaction system was adjusted from 6.0 to 9.0. The different 
concentrations of PLP were added $(0,1,3,5,7,9 \mathrm{mM})$ and $\mathrm{Mg}^{2+}$ was added in concentrations of $1,2,3,4$ and $5 \mathrm{mM}$. After adding recombinant $C$. crenatum cells, the reaction solution was incubated at different temperatures $\left(30{ }^{\circ} \mathrm{C}, 40{ }^{\circ} \mathrm{C}, 50\right.$ and $\left.60{ }^{\circ} \mathrm{C}\right)$ for $12 \mathrm{~h}$. After the reaction, the solution was centrifuged, and the product was analyzed by HPLC. The conversion rate is the molar concentration of the product to the molar concentration of the substrate.

\section{Fed-batch fermentation and medium}

Corynebacterium crenatum SYPA as a chassis strain for agmatine production and LBG medium was used to culture $C$. crenatum and corresponding recombinant strains at $30^{\circ} \mathrm{C}$ and $180 \mathrm{rpm}$. A single colony was inoculated into $20 \mathrm{~mL}$ of primary seed medium and cultured at $30^{\circ} \mathrm{C}$ for $24 \mathrm{~h}$ in a $250 \mathrm{~mL}$ shake flask. The primary seed culture was inoculated to a $200 \mathrm{~mL}$ secondary seed medium and cultured at $30{ }^{\circ} \mathrm{C}$. If necessary, $10 \mu \mathrm{g} / \mathrm{mL}$ chloramphenicol was added to the seed medium. After $12 \mathrm{~h}$ cultivation, $200 \mathrm{~mL}$ of the secondary seed culture was inoculated to a 5 - $\mathrm{L}$ fermenter containing $2 \mathrm{~L}$ of the fermentation medium. The fermentation medium contained the following: $100 \mathrm{~g} / \mathrm{L}$ glucose, $50 \mathrm{~g} / \mathrm{L}$ corn steep liquor, $20 \mathrm{~g} / \mathrm{L}$ yeast extract, $2 \mathrm{~g} / \mathrm{L} \quad \mathrm{KH}_{2} \mathrm{PO}_{4}, 0.5 \mathrm{~g} / \mathrm{L} \quad \mathrm{MgSO}_{4} \cdot 7 \mathrm{H}_{2} \mathrm{O}$, $1 \mathrm{~g} / \mathrm{L} \mathrm{KCl}, 0.02 \mathrm{~g} / \mathrm{L} \mathrm{FeSO}_{4} \cdot 7 \mathrm{H}_{2} \mathrm{O}, 0.02 \mathrm{~g} / \mathrm{L} \mathrm{MnSO}_{4}$, and $30 \mathrm{~g} / \mathrm{L}\left(\mathrm{NH}_{4}\right)_{2} \mathrm{SO}_{4}$. The temperature and the airflow rate were maintained at $30{ }^{\circ} \mathrm{C}$ and $3 \mathrm{~L} / \mathrm{min}$, respectively. The $\mathrm{pH}$ was maintained at 7.0 by automatically adding $50 \%$ $\mathrm{NH}_{3} \cdot \mathrm{H}_{2} \mathrm{O}$ solution. The feeding solution comprises the following components: $600 \mathrm{~g} / \mathrm{L}$ glucose, $60 \mathrm{~g} / \mathrm{L}$ corn steep liquor, $12 \mathrm{~g} / \mathrm{L} \mathrm{KH}_{2} \mathrm{PO}_{4}, 3 \mathrm{~g} / \mathrm{L} \mathrm{MgSO}_{4} \cdot 7 \mathrm{H}_{2} \mathrm{O}, 100 \mathrm{~g} / \mathrm{L}$ $\left(\mathrm{NH}_{4}\right)_{2} \mathrm{SO}_{4}, 10 \mathrm{~g} / \mathrm{L}$ yeast extract.

\section{Assays of cell concentration, glucose and agmatine}

The absorbance at $562 \mathrm{~nm}$ wavelength $\left(\mathrm{OD}_{562}, 1 \mathrm{OD}_{562}\right.$ $=0.375 \mathrm{~g} / \mathrm{L}$ dry cell weight, $\mathrm{DCW})$ was measured using Ultraviolet spectrophotometer (UNICOTM-UV2000, UNICO, Shanghai, China) for quantification of cell growth. The concentration of glucose in the fermentation supernatant were detected with SBA-40 C biosensor (developed by the Biology Institute of the Shandong Academy of Sciences, Jinan, China).

The concentration of agmatine and $\mathrm{L}$-arginine was analyzed using the HPLC system (Agilent LC1260) equipped with an Agilent C18 $(5 \mu \mathrm{m}, 250 \times 4.6 \mathrm{~mm})$ and a UV detector. The chromatographic conditions were as follows: rate flow of $1 \mathrm{~mL} / \mathrm{min}$, temperature of $40{ }^{\circ} \mathrm{C}$ and wavelength of $338 \mathrm{~nm}$. The agmatine and $\mathrm{L}$-arginine were measured by OPA FMOC precolumn derivatization. The mobile phases required for agmatine and L-arginine detection were phase A and phase D. Phase A contained
$8 \mathrm{~g}$ sodium acetate and $225 \mu \mathrm{L}$ triethylamine per liter of aqueous solution, $\mathrm{pH}$ was adjusted to 7.2 with acetic acid, $5 \mathrm{~mL}$ tetrahydrofuran were added to the mixture. Phase D contained 6 g sodium acetate in $200 \mathrm{~mL}$ water, acetic acid was added to the solution and $\mathrm{pH}$ was controlled to 7.2 , then $400 \mathrm{~mL}$ methanol, $400 \mathrm{~mL}$ acetonitrile were added.

\section{Abbreviations \\ ADC: Arginine decarboxylase; PLP: Pyridoxalphosphate; IPTG: Isopropyl- $\beta$ - D-thiogalactopyranoside; HPLC: High-performance liquid chromatography; SDS-PAGE: Sodium dodecyl sulfate polyacrylamide gel electrophoresis.}

\section{Supplementary Information}

The online version contains supplementary material available at https://doi. org/10.1186/s12934-022-01742-3.

Additional file 1: Table S1. Strains and plasmids used in this study. Table S2. The score of prime stability after the mutation. Table S3. Primers used in this study.

\section{Acknowledgements}

Not applicable.

\section{Authors' contributions}

FY Designed and performed the experiments, wrote the manuscript. JX Designed the experiments, software and data analysis. YZ and YW Investigation and resources. MX Co-supervised the work, proofread and revised the manuscript. ZR Supervision, project administration and funding acquisition. All authors read and approved the final manuscript.

\section{Funding}

This work was supported by the National Key Research and Development Program of China (2021YFC2100900), the National Natural Science Foundation of China (32070035), the Key Research and Development Program of Ningxia Hui Autonomous Region (2019BCH01002), the Fundamental Research Funds for the Central Universities (JUSRP221012), the Project of Xinjiang Production and Construction Corps (2019AB009), and the 111 Project (111-2-06).

\section{Availability of data and materials}

All data involved in this study are included in this published article [and its additional files].

\section{Declarations}

Ethics approval and consent to participate Not applicable.

Consent for publication

Not applicable.

Competing interests

The authors declare that they have no competing interests.

Received: 22 September 2021 Accepted: 12 January 2022 Published online: 31 January 2022

References

1. Li G, Regunathan S, Barrow CJ, Eshraghi J, Cooper R, Reis DJ. Agmatine: an endogenous clonidine-displacing substance in the brain. Science. 1994;263:966-9. 
2. Akasaka N, Fujiwara S. The therapeutic and nutraceutical potential of agmatine, and its enhanced production using Aspergillus oryzae. Amino Acids. 2020;52:181-97.

3. Kwon EJ, Kim MM. Agmatine modulates melanogenesis via MITF signaling pathway. Environ Toxicol Pharmacol. 2017;49:124-30.

4. Kotagale NR, Taksande BG, Inamdar NN. Neuroprotective offerings by agmatine. Neurotoxicology. 2019;73:228-45.

5. Feyza A-K, Soundar R. Effect of chronic morphine treatment on the biosynthesis of agmatine in rat brain and other tissues. Life Sci. 2002;71:1695-701.

6. Piletz JE, Aricioglu F, Cheng JT, Fairbanks CA, Gilad VH, Haenisch B, Halaris A, Hong S, Lee JE, Li J, et al. Agmatine: clinical applications after 100 years in translation. Drug Discov Today. 2013;18:880-93.

7. He H, Liu M, Zheng Z, Liu Y, Xiao J, Su R, Hu C, Li J, Li S. Synthesis and analgesic activity evaluation of some agmatine derivatives. Molecules. 2006;11:393-402.

8. Zhang $Y$, Zhou H, Tao Y, Lin B. Reconstitution of the ornithine cycle with arginine:glycine amidinotransferase to engineer Escherichia coli into an efficient whole-cell catalyst of guanidinoacetate. ACS Synth Biol. 2020:9:2066-75.

9. Song J, Zhou C, Liu R, Wu X, Wu D, Hu X, Ding Y. Expression and purification of recombinant arginine decarboxylase (speA) from Escherichia coli. Mol Biol Rep. 2010;37:1823-9.

10. Charlier D, Bervoets I. Regulation of arginine biosynthesis, catabolism and transport in Escherichia coli. Amino Acids. 2019;51:1103-27.

11. Yang D, Park SY, Park YS, Eun H, Lee SY. Metabolic engineering of Escherichia coli for natural product biosynthesis. Trends Biotechnol. 2020;38:745-65.

12. Pontrelli S, Chiu TY, Lan El, Chen FY, Chang P, Liao JC. Escherichia coli as a host for metabolic engineering. Metab Eng. 2018;50:16-46.

13. Xu D, Zhang L. Metabolic engineering of Escherichia coli for agmatine production. Eng Life Sci. 2019;19:13-20.

14. Xu D, Zhang L. Increasing agmatine production in Escherichia coli through metabolic engineering. J Agric Food Chem. 2019;67:7908-15.

15. YanHui Z, Wuke J, AiCun G, BoTong S, JianGuo Y. Production of agmatine from arginine by enzyme transformation. Food Ferment Ind. 2019;45:40-4.

16. Becker J, Zelder O, Hafner S, Schroder H, Wittmann C. From zero to hero--design-based systems metabolic engineering of Corynebacterium glutamicum for L-lysine production. Metab Eng. 2011;13:159-68.

17. Zhang X, Han R, Bao T, Zhao X, Li X, Zhu M, Yang T, Xu M, Shao M, Zhao Y, Rao Z. Synthetic engineering of Corynebacterium crenatum to selectively produce acetoin or 2,3-butanediol by one step bioconversion method. Microb Cell Fact. 2019;18:128.

18. Chen $X$, Wu X, Jiang S, Li X. Influence of $\mathrm{pH}$ and neutralizing agent on anaerobic succinic acid production by a Corynebacterium crenatum strain J Biosci Bioeng. 2017;124:439-44.

19. Schneider J, Niermann K, Wendisch VF. Production of the amino acids L-glutamate, $\mathrm{L}$-lysine, $\mathrm{L}$-ornithine and $\mathrm{L}$-arginine from arabinose by recombinant Corynebacterium glutamicum. J Biotechnol. 2011;154:191-8.

20. Park SH, Kim HU, Kim TY, Park JS, Kim SS, Lee SY. Metabolic engineering of Corynebacterium glutamicum for L-arginine production. Nat Commun. 2014:5:4618.

21. Xu M, Rao Z, Dou W, Yang J, Jin J, Xu Z. Site-directed mutagenesis and feedback-resistant $N$-acetyl-L-glutamate kinase (NAGK) increase Corynebacterium crenatum L-arginine production. Amino Acids. 2012:43:255-66.

22. Xu M, Tang M, Chen J, Yang T, Zhang X, Shao M, Xu Z, Rao Z. Pll signal transduction protein GInK alleviates feedback inhibition of N-Acetyl-I-glutamate kinase by L-arginine in Corynebacterium glutamicum. Appl Environ Microbiol. 2020;86:e00039-00020.

23. Sun $X$, Song $W$, Liu L. Enzymatic production of agmatine by recombinant arginine decarboxylase. J Mol Catal B Enzym. 2015;121:1-8.

24. Xu M, Rao Z, Yang J, Xia H, Dou W, Jin J, Xu Z. Heterologous and homologous expression of the arginine biosynthetic $\arg \mathrm{C} \sim \mathrm{H}$ cluster from Corynebacterium crenatum for improvement of L-arginine production. J Ind Microbiol Biotechnol. 2012;39:495-502

25. Ginesy M, Belotserkovsky J, Enman J, Isaksson L, Rova U. Metabolic engineering of Escherichia coli for enhanced arginine biosynthesis. Microb Cell Fact. 2015;14:29.
26. Stim KP, Bennett GN. Nucleotide sequence of the adi gene, which encodes the biodegradative acid-induced arginine decarboxylase of Escherichia coli. J Bacteriol. 1993:175:1221-34.

27. Rodrigez BR, Carroll DW, Mitchell D, Momany C, Hackert ML. Crystallization of biosynthetic arginine decarboxylase from Escherichia coli. Acta Crystallogr. 2010;50:175-7.

28. Choi H, Kyeong HH, Choi JM, Kim HS. Rational design of ornithine decarboxylase with high catalytic activity for the production of putrescine. Appl Microbiol Biotechnol. 2014;98:7483-90.

29. Kai Y, Kashiwagi T, Ishikawa K, Ziyatdinov MK, Redkina El, Kiriukhin MY, Gusyatiner MM, Kobayashi S, Takagi H, Suzuki E. Engineering of Escherichia coli L-serine $\mathrm{O}$-acetyltransferase on the basis of crystal structure: desensitization to feedback inhibition by L-cysteine. Protein Eng Des Sel. 2006:19:163-7.

30. Han S-S, Kyeong H-H, Choi JM, Sohn Y-K, Lee J-H, Kim H-S. Engineering of the conformational dynamics of an enzyme for relieving the product inhibition. ACS Catal. 2016;6:8440-5.

31. Grillo MA, Colombatto S. Arginine revisited: minireview article. Amino Acids. 2004;26:345-51.

32. Rocha JF, Pina AF, Sousa SF, Cerqueira NMFSA. PLP-dependent enzymes as important biocatalysts for the pharmaceutical, chemical and food industries: a structural and mechanistic perspective. Catal Sci Technol. 2019;9:4864-76.

33. Forouhar F, Lew S, Seetharaman J, Xiao R, Acton TB, Montelione GT, Tong L. Structures of bacterial biosynthetic arginine decarboxylases. Acta Crystallogr Sect F Struct Biol Cryst Commun. 2010;66:1562-6.

34. Tauch A, Kirchner O, Loffler B, Gotker S, Puhler A, Kalinowski J. Efficient electrotransformation of Corynebacterium diphtheriae with a mini-replicon derived from the Corynebacterium glutamicum plasmid pGA1. Curr Microbiol. 2002;45:362-7.

35. Sun A, Song W, Qiao W, Chen X, Liu J, Luo Q, Liu L. Efficient agmatine production using an arginine decarboxylase with substrate-specific activity. J Chem Technol Biotechnol. 2017:92:2383-91.

36. Bradford MM. A rapid and sensitive method for the quantitation of microgram quantities of protein utilizing the principle of protein-dye binding. Anal Biochem. 1976:72:248-54.

\section{Publisher's Note}

Springer Nature remains neutral with regard to jurisdictional claims in published maps and institutional affiliations.

Ready to submit your research? Choose BMC and benefit from

- fast, convenient online submission

- thorough peer review by experienced researchers in your field

- rapid publication on acceptance

- support for research data, including large and complex data types

- gold Open Access which fosters wider collaboration and increased citations

- maximum visibility for your research: over 100M website views per year

At BMC, research is always in progress.

Learn more biomedcentral.com/submissions 